\title{
IDEA KATOLICKIEGO MODERNIZMU W FILOZOFICZNYCH POSZUKIWANIACH MARIANA ZDZIECHOWSKIEGO
}

\begin{abstract}
Artykuł ten jest już kolejnym z cyklu tekstów podejmujących problematykę zagadnień etycznych, które pojawiają się w filozofii polskiej. Również po raz kolejny inspiracją jest koncepcja Mariana Zdziechowskiego, tym razem jednak przedstawione zostanie zagadnienie rzadko podejmowane w analizach i opracowaniach - problematyka inspiracji modernizmem katolickim w filozofii wileńskiego myśliciela. Marian Zdziechowski jest rodzajem pomostu między dwoma stuleciami, między romantyzmem i pozytywizmem, między racjonalizmem i idealizmem, między ideami wschodu i zachodu, między logicznym pojmowaniem świata i ujęciem metafizycznym, między pascalowską wiarą i rozumem. W swych rozważaniach jednak podążał indywidualną drogą, nie pasował do żadnych mód filozoficznych, konsekwentnie trwając przy własnych pryncypiach światopoglądowych ${ }^{2}$.

Marian Zdziechowski próbował uzasadnić możliwość i konieczność wiary w Boga w obliczu wszechogarniającego zła świata. Podejmując polemikę ze świętym Augustynem i ulegając kolejnym fascynacjom myślicieli, takich jak Schopenhauer, Sołowjow czy Schopenhauer, próbował odnależć odpowiedź na - chyba dla mysliciela najważniejsze pytania dotyczące przyczyn i możliwości przezwyciężenia zła. Budując swój filozoficzny światopogląd w książce Pesymizm, romantyzm i podstawy chrześcijaństwa, Zdziechowski włączał także idee modernizmu katolickiego do swoich intelektualnych poszukiwań. Zadawał podstawowe pytania o modernizm jako wyzwania dla współczesnej wiary oraz o możliwość dialogu z nowymi trendami.

Poszukując odpowiedzi na różnych płaszczyznach, także takich, które służyły pogłębionej refleksji religijnej, przyjmował postawę intelektualisty zaangażowanego w myśl chrzescijańską, jednak wolną od uprzedzeń i lęków przed kreatywnym poszukiwaniem. Celem opracowania jest próba przybliżenia idei modernizmu katolickiego w ujęciu Mariana Zdziechowskiego, ze szczególnym uwzględnieniem problematyki zła i związanego z nią pesymizmu.
\end{abstract}

Słowa kluczowe: modernizm katolicki, chrześcijaństwo, zło, Zdziechowski.

\section{WSTEP}

Życie Mariana Zdziechowskiego przypadło na okres aż pięciu pontyfikatów ${ }^{3}$ i nauczanie Soboru Watykańskiego. Dodatkowo tworzył na pograniczu dwóch stuleci, a co

\footnotetext{
${ }^{1}$ Dr Justyna Stecko, Zakład Nauk Humanistycznych, Wydział Zarządzania, Politechnika Rzeszowska, ul. Poznańska 1, 35-084 Rzeszów, tel. 1786512 04, e-mail: jstecko@prz.edu.pl

${ }^{2}$ Por. E.N. Wesołowska, Działać przed katastrofa, Warszawa 1994, s. 9.

${ }^{3}$ Piusa IX (1846-1878), Leona XIII (1878-1903), Piusa X (1903-1914), Benedykta XV (19141922) i Piusa XI (1922-1939).
} 
za tym idzie - był świadkiem zmierzchu jednych idei i rodzeniu się nowych ${ }^{4}$. Odchodził romantyzm z jego ideami mesjanistycznymi, rodził się zaś pozytywizm. Zdaniem Stanisława Stommy Zdziechowski „był i pozostał romantykiem, ale żyjąc w dobie pozytywizmu ulegał także jego wpływom [...]. Można powiedzieć, że wyznawał romantyzm racjonalnie kontrolowany, bowiem w rygorach myślowych Zdziechowski był pozytywistą"5. W romantyzmie brakowało mu precyzyjnego, logicznego myślenia, W pozytywizmie zaś - pierwiastka metafizycznego. Sam o sobie mówił: ,jestem niepotrzebnym, spóźnionym epigonem epoki romantycznej"6. Moim zdaniem Zdziechowskiego nie powinniśmy traktować jak zagubionego w opozycyjnych ideach, ale raczej jako rodzaj łącznika, nawet pomostu między dwoma stuleciami, między romantyzmem i pozytywizmem, między racjonalizmem a idealizmem, między ideami wschodu i zachodu, między logicznym pojmowaniem świata a ujęciem metafizycznym, między pascalowską wiarą a rozumem.

\section{W KIERUNKU MODERNIZMU}

Należy najpierw przybliżyć pojęcie modernizmu ${ }^{7}$ Główną inspiracją modernizmu były osiągnięcia dziewiętnastowiecznej nauki oraz filozofii. Jak pisze Roman Padoł: „modernizm katolicki to określenie szerokiego, różnorodnego i dość powszechnego ruchu w katolicyzmie w pierwszych latach XX wieku, choć jego początki sięgają [...] połowy ubiegłego stulecia. [...] Ruch ten przejawiał się w dziedzinie doktrynalnej i dotyczył filozofii, dogmatyki, krytyki biblijnej, historii religii oraz w działalności politycznospołecznej pojawił się jako tendencja reformistyczna zbliżona do liberalizmu lub nawet do socjalizmu. [...] Modernizm katolicki był ujmując generalnie, próbą nowej interpretacji religii pod hasłem uzgodnienia jej ze świadomością nowoczesną. Powszechnie też stwierdzono, że religia opiera się na irracjonalnych źródłach i jest wcześniejsza od jej intelektualnego wyrazu - teologii - jak życie od jego intelektualnej analizy. Jako jedna z dziedzin życia, religia podlega rozwojowi, ewolucji. Tak więc [...] poznanie religijne przekracza zakres myśli i sprowadza się do przeczucia, wiary, która ,jest gwałtem zadanym rozumowi. W duchu subiektywizmu ujęto wiarę jako rezultat wewnętrznego doświadczenia, zmysłu religijnego - sensus religiosus - indywidualnego doświadczenia"8. Na postawie tego dość długiego fragmentu widać, że jest to rozległy i złożony problem, w którym trudno o jednolite zasady i koncepcje. Niektórzy są zdania, że dopiero encyklika Pascendi Dominici gregis z 1907 roku wydana przez papieża Piusa X przyczyniła się do ujednolicenia tego kierunku. Jak stwierdził Tyrrell, rzeczywistym twórcą modernizmu był

\footnotetext{
${ }^{4} \mathrm{O}$ zmianach nurtów myślowych: pozytywizmu, antypozytywizmu czy Młodej Polski - zob. S. Jedynak, Etyka polska w latach 1863-1918, Warszawa 1977, s. 6 n.

${ }^{5}$ S. Stomma, Oczyma świadka, [w:] J. Skoczyński, Wartość pesymizmu, Kraków 1994, s. 10.

${ }^{6}$ M. Zdziechowski, Szkice literackie, Warszawa 1900, s. 2.

${ }^{7}$ Jan Kracik zauważa, że po raz pierwszy pojęcia „modernizm” użył fryburski dogmatyk Carl Braig we wstępie do tłumaczonej Apologii chrystianizmu (w 1885 r.). Por. J. Kracik, Antymodernistyczna kampania, „Znak” 2002/7, s. 30-44, http://www.znak.com.pl/ znak/kracik566.html.

${ }^{8}$ R. Padoł, Filozofia religii polskiego modernizmu, Wydawnictwo Literackie, Kraków 1982, s. 29, $42-43$.
} 
papież. Jego zarzuty scalają owa koncepcję w pewną całość. Jednak jego encyklika jest zarazem najgorszym źródłem zrozumienia głównych cech owego zjawiska ${ }^{9}$.

Wraz z Piusem X kościół zmienił znacząco podejście do koncepcji modernistycznych, uczulono biskupów na przejawy takich idei oraz pojawił się oficjalny indeks ksiąg zakazanych. Od 1910 r. zaczęła obowiązywać przysięga antymodernistyczna, która miała zapobiec rozprzestrzenianiu modernistycznych koncepcji w doktrynie katolickiej.

\section{MODERNIZM W UJECIU MARIANA ZDZIECHOWSKIEGO}

Niniejsze opracowanie jest jedynie wybiórczym spojrzeniem na koncepcje wybranych modernistów przez pryzmat pesymizmu i związanego z nim zła. Modernizm wywołał wiele emocji i łatwo w tych czasach było o niełaskę Kościoła, a nawet ekskomunikę. Problem modernizowania katolicyzmu jest dla Zdziechowskiego głównie powiązany z kwestią zła i możliwością jego przezwyciężenia. Zdziechowski, jednocześnie będąc wierny Kościołowi i sympatyzując z modernistami, z którymi w dużej mierze się zgadzał, przekazywał ich postulaty od siebie nie wprost, ale za pomoca prezentowania sylwetek znanych propagatorów i twórców tych koncepcji, takich jak Newman, Tyrrell czy Blondell. Jak sugerują niektórzy badacze myśli Zdziechowskiego, problem powiązania tegoż myśliciela z modernizmem został zaniedbany ${ }^{10}$.

Zainteresowanie Zdziechowskiego modernizmem wyznaczają daty ukazania się dwóch jego prac: Szkice literackie i Pesymizm, romantyzm a podstawy chrześcijaństwa ${ }^{11^{q}}$. Jednak czasy te były niezwykle trudne dla mediatorów ruchu modernistycznego z Kościołem katolickim. Zdziechowski porównuje modernizm do przesilenia w Kościele XIII w., dzieła modernistów zaś do filozofii Arystotelesa. Na początku go potępiono, ale później za sprawą świętego Tomasza zrehabilitowano i z ,arystotelizmu uczyniono podstawę katolickiej doktryny. Teraz - dodaje sarkastycznie Zdziechowski - w imię arystotelizmu prześladuje się modernistów”'2 . „Moderniści byli katolikami, którzy wyraźniej niż hierarchia i masy - dostrzegali potrzebę aggiornamento Kościoła" ${ }^{\prime 13}$. Nie chcieli oni go opuszczać, ale odnowić i oczyścić. $Z$ dzisiejszej perspektywy można ich określić mianem pionierów ekumenizmu. Przekonani, że w każdej religii można odnaleźć cząstkę bożej mądrości, przedstawili poglądy współczesnych reformatorów Kościoła.

Prekursorem modernistów wydaje się Pascal. Ten niezwykle nowoczesny myśliciel długo przed modernistami postulował obronę zarówno rozumu, jak i wiary. Jego zdaniem nie należy poniżać żadnego z porządków: ani rozumu, ani wiary. Sam Zdziechowski zaś upatruje źródeł modernizmu katolickiego ${ }^{14}$ w myśli Kanta i Schopenhauera, której jednak

\footnotetext{
${ }^{9}$ Por. L. Kołakowski, Uwaga o modernizmie, „Znak” 2002/7, s. 14.

${ }^{10}$ Por. J. Skoczyński, Pesymizm filozoficzny Mariana Zdziechowskiego, s. 48, także J. Skoczyński, Sympatyk modernizmu religijnego, „Znak” 1983/8.Także w polskim piśmiennictwie brak analiz dotyczących tematu modernizmu katolickiego. Podobnego zdania jest Leszek Kołakowski, Uwaga o modernizmie, „Znak” 2002/7, s. 13.

${ }^{11}$ O tym J. Skoczyński, Sympatyk modernizmu..., s. 1236.

${ }^{12}$ Ibidem, także J. Skoczyński, Pesymizm filozoficzny Mariana Zdziechowskiego, s. 48.

${ }^{13}$ Ks. J. Kracik, Antymodernistyczna kampania..., s. 33.

${ }^{14}$ Jan Skoczyński używa pojęcia religijny a nie katolicki, gdyż Zdziechowski dostrzegał w modernizmie wpływy innych wyznań chrześcijańskich. J. Skoczyński, Sympatyk modernizmu
} 
nie da się zamknąć w jednej tezie. Kant nie tylko po rozdzieleniu rozumu na teoretyczny i praktyczny pozbawił pierwszy z nich możliwości wyrokowania na temat zagadnień metafizycznych, ale także miał wpływ na pobudzenie irracjonalizmu i mistycyzmu, czego efektem jest właśnie filozofia Schopenhauera ${ }^{15}$. Oprócz refleksji na temat tych myślicieli w dziele Pesymizm, romantyzm a podstawy chrześcijaństwa pojawiają się całe rozdziały na temat Newmana, Laprunea, Blondela, Laberthonnierea czy Tyrrella.

W zakresie myśli religijnej dla Mariana Zadziechowskiego niekwestionowanym autorytetem był kardynał Newman, podstawowym zagadnieniem zaś - wiara ${ }^{16}$. Newman zakwestionował optymizm scholastyków dotyczący zgodności wiary i rozumu, a także ich przekonania dotyczącego racjonalnych fundamentów: „Bezsilne i bezowocne są wszelkie apologie, które do rozumu się zwracają: prawdy wiary nie dają się udowodnić; mogą tylko być uprawdopodobnione, wykazanie zaś prawdopodobieństwa nikogo nie nawróci"17. Stąd potrzebny jest nowy model wiary, na której fundamencie będzie można się oprzeć w walce ze złem. Kluczem do wiary, zdaniem Newmana, nie jest i nie będzie rozum: „dowodzenie w rzeczach wiary jest taką samą niedorzecznością jak tortury”18. Jedynie poznanie „sercem” ma szansę na odkrycie Boga, a co za tym idzie - potencjalną możliwość odnalezienia broni przeciwko złu.

Tyrrell - drugi z czołowych modernistów, a zarazem kolejna postać inspirująca Zdziechowskiego - zaakcentował jeszcze bardziej różnicę między wiarą a rozumem. Między nimi jest przepaść, którą jedynie łaska może zniweczyć. Wiara, jego zdaniem, to gwałt zadany rozumowi ${ }^{19}$. To credo quia absurdum wskazuje na istotę religii. Niedostępne tajemnice, które często zdają się nam paradoksami, są charakterystyczne dla wiary. Jeżeli próbujemy ująć w ramy intelektualne to, co nie do odkrycia i zrozumienia, dochodzimy albo do stwierdzenia absurdu, albo do pokory. Należy stwierdzić, że niektóre zagadnienia religijne przedstawiają niemożliwe do rozwiązania trudności. Gdyby religię można było zrozumieć bez problemu, byłaby „rzeczą” ludzką, nie boską, zasługiwałaby nie na wiarę, ale status nauki. Tyrrell - zdaniem Zdziechowskiego - zrozumiał trudność wiary, zauważył, że ona jest czymś sprzecznym $\mathrm{z}$ najszlachetniejszymi aspiracjami człowieka, owym gwałtem dla rozumu. Prawdziwych trudności nie sposób przezwyciężyć przez racjonalną dedukcję, która była charakterystyczna dla teologii, ponieważ wypływają one $\mathrm{z}$ głębi człowieka, $\mathrm{z}$ jego nieracjonalnej sfery. Przepaść dzieli wiarę przeciętnego człowieka od nauk teologów. Rozumową analizę terminologii dotyczącej wiary można porównać, zdaniem Tyrrella, do twierdzenia, że chemiczna analiza chleba i wina może objaśnić sakrament Eucharystii ${ }^{20}$. Tyrrell mimo ekskomuniki i odrzucenia pozostał wierny

religijnego..., s. 1235. Autorka niniejszej pracy jednak zgodnie z intencją i nazewnictwem stosowanym przez Zdziechowskiego używa pojęcia „katolicki”. Mimo wpływu innych prądów Zdziechowski był zainteresowany właśnie modernizacją katolicyzmu jako jego wyznawca. W tym miejscu można mówić o możliwości różnego ujęcia tegoż zagadnienia.

${ }^{15} \mathrm{O}$ źródłach modernizmu w myśli M. Zdziechowskiego - zob. J. Skoczyński, Wartość pesymizmu, s. 48-57, a także J. Krasicki, Eschatologia i mesjanizm. Studium światopogladu Mariana Zdziechowskiego, Warszawa 1994, s. 197-202

${ }^{16}$ Ciekawe ujęcie problemów społecznych w myśli Newmana - zob. P. Kłoczowski, Liberalizm kardynała Newmana, „Znak” 1983/8, s. 1254-1265.

${ }^{17}$ M. Zdziechowski, Pesymizm, romantyzm a podstawy chrześcijaństwa, t. II, s. 170.

${ }^{18}$ Ibidem, s. 173.

${ }^{19}$ Por. ibidem, s. 287.

${ }^{20}$ Ibidem, s. 315. 
wierze, przede wszystkim dlatego, że upatrywał w niej, podobnie jak Newman, możliwości przezwyciężenia zła.

W odpowiedzi zarówno jednego, jak i drugiego myśliciela Zdziechowski dostrzega element pesymizmu. Newman, podobnie jak wileński filozof, nie godzi się na odpowiedź Augustyna, który traktował zło jako niezbędny warunek dobra. W W swoich poszukiwaniach Newman odwołuje się do sumienia, które traktuje jako swego rodzaju autorytet, starający się dyktować nam prawo moralne, a także rozstrzygać, co jest dobrem, a co złem. Bez poczucia grzechu nie ma szczerej religii i wszystko, co się za nią podaje, jest tylko jej imitacją. Religia nie jest jednak czymś łatwym. Jej podstawą jest poczucie grzeszności, całe nasze życie to gnębiący pesymizm, a koniec bez gwarancji, że zostaniemy zbawieni. Symbol grzechu pierworodnego to - zdaniem Zdziechowskiego nie tylko głębia pesymizmu, ale także możliwość jego przezwyciężenia. $Z$ jednej strony dogmat ten wskazuje na upadek człowieka, niemożliwość pokonania go własnymi siłami, wprowadza nas w smutną świadomość, że zło jest treścią bytu, ale z drugiej wskazuje na możliwość przezwyciężenia tego upadku. Z pomocą przychodzi nam instytucja Kościoła. Mimo że z działaniem owej instytucji wiąże się wiele problemów, to jednak „dziesięć tysięcy trudności nie tworzą [...] jednego wątpienia, trudność i wątpienie nie są współmierne" ${ }^{\text {21 }}$. Stąd ani Newman, ani za nim Zdziechowski nie poddali Kościoła krytyce w takim stopniu, jak zrobił to jego następca Tyrrell. Rozwiązanie problemu przez Newmana jest łudząco podobne do myśli Kanta, którego nigdy nie czytał, i Schopenhauera, o który nie wiedział nawet, że istnieje ${ }^{22}$. Zdziechowski zauważa, że Newman, podobnie jak Kant, rozgraniczył świat zjawisk i istotę rzeczy, stawanie się i byt. Przeniósł problematykę moralną na grunt rozumu praktycznego, ale co najważniejsze sumienie potraktował jako naczelną podstawę religii naturalnej. Jednak Newman nie rozwiązywał zagadnień teorii poznania, nurtowały go raczej kwestie moralne. Chciał odnaleźć drogę, dzięki której przezwycięży zło, czyli drogę do Boga. Zauważona przez Zdziechowskiego zbieżność $\mathrm{z}$ Schopenhauerem to odczucie dysonansu między odczuwaną rzeczywistością, w której jaskrawo widoczne jest zło, a marzeniami - w wypadku Newmana - na temat dobrego Boga. Pesymizm Newmana jest nie tylko efektem pracy rozumu, który potrafi każdą prawdę „,choćby najświętszą” zakwestionować, ale i lęku przed karą za grzechy, wiecznym potępieniem i odsunięciem się od Boga ${ }^{23}$.

Zdziechowski doszukał się w filozofii Newmana nie tylko elementów destrukcyjnych, ale i nadziei oraz możliwości przezwyciężenia w pełni pesymizmu. Koncepcja ta, jego zdaniem, daje podstawy do sprzeciwu i walki ze złem. Wskazuje drogę, która pozwala wygrać ze złem. Choć nie jest to droga łatwa, ponieważ pokusa wygodnego życia dla każdego jest atrakcyjna, to jednak jest realna. Według Zdziechowskiego z koncepcją Newmana dotyczącą problematyki zła koresponduje pesymistyczna myśl Tyrrella. On również stanął przed dylematem: albo Boga nie ma, albo nie jest on dobrem najwyższym. „A jednak uświadomienie sobie zagadnienia tego nie przejęło Tyrrella grozą, nie wywołało w nim posępnych rozmyślań o nędzy człowieka przed Bogiem [...]"24. Odnalazł on wyjście we wszechogarniającej wierze i przekonaniu, które odnalazł w głębi siebie, że

\footnotetext{
${ }^{21}$ Ibidem, s. 196

${ }^{22}$ Por. ibidem, s. 190.

${ }^{23}$ Por. J. Skoczyński, Pesymizm filozoficzny Mariana Zdziechowskiego..., s. 45.

${ }^{24}$ M. Zdziechowski, Pesymizm ..., s. 288.
} 
Bóg to przede wszystkim ogromna, niewyobrażalna Miłość. Gniew Boga nie jest konsekwencją tego, że obraziliśmy Go, ale troską o nas. Porównuje go do gniewu matki, która zauważyła, że jej dziecko bawi się ogniem. Grzech, którego jesteśmy sprawcami, nie szkodzi Bogu, ale nam samym. „On wie, że tracąc Jego, tracimy wszystko ”25. Wydaje się, że Mariana Zdziechowskiego przed skrajnym pesymizmem, a być może również przed nihilizmem, uratowała ogromna i głęboka wiara w Boga.

\section{PROBLEMATYKA ZLA}

Marian Zdziechowski poszukiwał także u myślicieli modernistycznych odpowiedzi dotyczącej problematyki zła. Na pytanie o zło, czym jest i skąd się wzięło, nie ma innej odpowiedzi jak ta, że „Bóg istnieje, a rozbrzmiewa ona tym donośniej, im większym bólem przejmuje nas zło, im śmielej i namiętniej do walki $z$ nim idziemy"26. Zdziechowski, zgodny w tej kwestii z Tyrrellem, skłonny jest zrezygnować z określenia, czym jest zło, i poszukiwania jego źródeł na rzecz czynnego przeciwstawienia mu się. Kwestia ta jawi mu się jako ważniejsza. Tym bardziej że wielorakie poszukiwania nie dały mu odpowiedzi. Wydaje się, że w tym miejscu Zdziechowski zdecydowanie rezygnuje z płaszczyzny metafizycznej i przenosi się na egzystencjalną; choć próby takie były już wcześniej zauważalne ${ }^{27}$. Tyrrell nakłania do rezygnacji z zaangażowania w świat, w którym panuje tyle zła; do przeciwstawienia się mu i przezwyciężenia, dzięki temu przyczynimy się do realizacji dzieła Bożego. Świętość, zdaniem Tyrrella, to najlepsza broń przeciw złu. Jednak nie był on optymistą. Ze smutkiem stwierdza, że gdyby „Kościół nawet z samych świętych był złożony"28, to najprawdopodobniej trudno byłoby uratować świat przed złem. Jego pesymizm pogłębiały spostrzeżenia na temat sposobu edukacji duchownych i rozwój instytucji Kościoła. Duchowni odcięci od świata nie mają pojęcia o największym złu. Dodatkowo uczeni teologii jako racjonalnej dyscypliny najprawdopodobniej nie porwą serc. „Umysły przez teologię kościelną ukształtowane nie zdołają nigdy do człowieka współczesnego zrozumiałym dla niego językiem przemówić" 29 . To, że Chrystus nie był teologiem, trudne było do zrozumienia dla ówczesnych duchownych.

Zło okazuje się u Tyrrella i interpretującego go Zdziechowskiego także pierwiastkiem pozytywnym. Opór, który trzeba stawić w walce $\mathrm{z}$ nim, jest warunkiem niezbędnym naszego rozwoju duchowego. Bóg ,,[...] w nas i przez nas walczy z niewiedzą, z błędem, z samolubstwem, $\mathrm{z}$ cierpieniem, $\mathrm{z}$ grzechem [...]"30. Aby zagadnienia te były bardziej zrozumiałe dla ,przeciętnego wyznawcy”, potrzebne są pewne wyobrażenia, symbole. Zło to nie jakaś „abstrakcja, lecz Szatan, który je uosabia" ${ }^{\text {31 }}$. Nie bójmy się takich określeń, to one właściwie pomagają zobaczyć nam grozę grzechu. Główną przyczyną grzechu jest

\footnotetext{
${ }^{25}$ Ibidem, s. 289.

${ }^{26}$ Ibidem, s. 293

${ }^{27}$ J. Skoczyński nazwisko Newmana kojarzy z rezygnacją z owych poszukiwań. Różnica nie jest wielka, jednak jeszcze u Tyrrella pojawia się pytanie - skąd zło? Dlatego wydaje mi się słuszne, aby kojarzyć ten właśnie przełom z jego nazwiskiem.

${ }^{28}$ M. Zdziechowski, Pesymizm..., s. 278.

${ }^{29}$ Ibidem, s. 278.

${ }^{30}$ Ibidem, s. 305

${ }^{31}$ Ibidem, s. 359.
} 
diabeł, a efektem - realne zło. Stąd Tyrrell wielokrotnie mówi o królestwie szatana, które należy zniszczyć. Grzech jest nie tylko przewinieniem wobec samego siebie czy społeczeństwa, ale również ,jest buntem przeciw Najwyższemu Dobru, jest zdradą Boga"32, czyli gloryfikowaniem Szatana. Wydaje się, że Zdziechowski, zainspirowany myślą Tyrrella, również odważył się użyć pojęcia diabła, gdy myślał o urzeczywistnionym złu. Pojęcie to było dla ówcześnie żyjących przeżytkiem, średniowiecznym wykopaliskiem. Podobnie jest współcześnie. Przez ostatnie wieki mówienie o szatanie jako czynniku zła było i jest nie tylko niemodne, ale również kompromituje naszą nowoczesność. W tym miejscu można się odwołać do interpretacji Leszka Kołakowskiego i jego idei diabła jako metafory zła ${ }^{33}$.

Podobnie jak była mowa o uosobieniu zła, można mówić o wyobrażeniu dobra. Na Ziemi zostało ono urzeczywistnione w postaci Jezusa. Chrystus jest nam nauczycielem, przewodnikiem, tym który - jak mówi Zdziechowski - próbuje opisać barwy wszystkim ślepcom, którzy tego zapragną.

Zdaniem Zdziechowskiego bardzo ważna jest walka $\mathrm{z}$ charakterystycznym w ówczesnych czasach ,płytkim optymizmem” i uświadomienie sobie prawdy zapisanej w Ewangelii, na którą się powoływał właśnie Tyrrell. Prawdy dotyczącej naszego życia doczesnego, która nie jest optymistyczna. Każdy z nas dokładnie wie, że czeka go śmierć, która jest nieunikniona, co więcej, nie znamy nawet jej przybliżonego terminu ani postaci w jakiej przyjdzie; dla ludzi wierzących zaś istnieje dodatkowa obawa przed sądem, który będzie przeprowadzony po śmierci. Świadomość ta powinna usposabiać pesymistycznie. Ten rodzaj pesymizmu podkreśla nieuchronność śmierci, skończoność i niedoskonałość świata, obecność zła i prowadzi nas bezpośrednio ku zagadnieniom eschatologicznym.

Wyjściem z pesymizmu, a zarazem pomostem do Boga jest w człowieku zmysł religijny, który Tyrrell określa jako „połączenie zmysłu moralnego ze zmysłem mistycznym" ${ }^{34}$. Jest to niezwykle ważne pojęcie także w filozofii Mariana Zdziechowskiego. W odpowiedziach na temat możliwości przezwyciężenia zła to właśnie zmysł religijny odgrywa bardzo ważną rolę. „Jest to głód Boga, to korona natury człowieka [...], która pozwala nam na wyjście poza zmysłowy skończony świat. Jest to narzędzie, które pozwala umniejszyć siłę zła”35.

Zdaniem Zdziechowskiego Tyrrell uchwycił sedno przesłania Ewangelii. Zauważył, że świat podporządkowany jest złu, ale człowiek powinien uświadomić sobie tę prawdę i nie pozostać wobec niej obojętny. Co więcej, realne są tylko dwie alternatywy: albo Bóg, albo diabeł, pomiędzy nie ma nic. „Królestwo Boże [...] i królestwo szatana, są to dwie korelatywne idee ${ }^{, 36}$, między nimi toczy się walka, człowieka zaś musi wybrać, po której ze stron chce się znaleźć. W tym miejscu można odnaleźć inspiracje myślą świętego Augustyna. Zdziechowski nie akceptuje rozwiązania zaproponowanego przez świętego na

\footnotetext{
${ }^{32}$ Ibidem, s. 359.

${ }^{33}$ Por. J. Stecko, Próba współczesnej interpretacji koncepcji diabła jako metafory zła na przykładzie myśli Leszka Kołakowskiego [w:] Etyka a zło, red. D. Probucka, Kraków 2013, s. 196-206.

${ }^{34}$ M. Zdziechowski, Pesymizm..., s. 328.

${ }^{35}$ Ibidem, s. 292.

${ }^{36}$ Ibidem, s. 307.
} 
płaszczyźnie ontologicznej, jednak wydaje się, że wraz z myślą Tyrrella zgadza się na interpretację egzystencjalno-moralną ${ }^{37}$.

\section{ZAKONCZENIE}

Marian Zdziechowski nie podchodził bezkrytycznie do koncepcji modernistycznej. Broniąc tego, co wartościowe, jednocześnie krytykuje inne elementy. Zauważa na przykład, że źle pojęty immanentyzm doprowadził niektórych do ukrytego ateizmu lub panteizmu. Byli zaś nawet tacy, którzy ubierali „w szatę katolicką [...] zupełny nihilizm religijny, ażeby go do Kościoła przemycić ${ }^{, 38}$. Zdziechowski zarzuca także bunt przeciwko autorytetowi i brak karności wobec instytucji Kościoła. Moderniści stawiali w opozycji pojęcie własnego sumienia i autorytetu, wywyższyli też nad miarę element subiektywny. Zbłądzili także tym, że zapatrzeni w nowatorstwo i postęp nie zauważyli, iż w swoim zaślepieniu zbliżyli się do nurtów antyreligijnych ${ }^{39}$. Mimo tych zarzutów w myśli modernistycznej Zdziechowski widzi urzeczywistnienie swego głównego celu - otwarcia się na to, co jest dobrem, nawet jeżeli znajduje się poza ramami Kościoła katolickiego; co za tym idzie - możliwości dialogu międzykulturowego, owej syntezy Wschodu z Zachodem. To jak bardzo zależało Zdziechowskiemu na komunikacji oficjalnego Kościoła z modernizującymi myślicielami, świadczy m.in. fakt audiencji u papieża i obrona nowoczesnych ujęć wiary. Zdziechowski wskazywał na pozytywne i potrzebne aspekty postulatów modernistów. Choć ze spotkania z namiestnikiem Kościoła wyniósł bardzo dobre wrażenie. Okazało się jednak, że radość była przedwczesna. Niedługo po tych mediacjach ukazała się encyklika Pascendi Dominici gregis, dogłębnie krytykująca myśl modernistyczną i zamykająca drogę dialogu z modernistami. Pominęłam w analizie myśl Olle-Laprune'a oraz Maurycego Blondela, którego myśl, zdaniem Zdziechowskiego, stanowi apogeum dziewiętnastowiecznego pesymizmu. Jest to jednak już zagadnienie, któremu należy poświęcić niezależne opracowanie.

\section{LITERATURA}

[1] Jedynak S., Etyka polska w latach 1863-1918, Warszawa 1977.

[2] Kłoczowski P., Liberalizm kardynała Newmana, „Znak” 1983/8.

[3] Kołakowski L., Uwaga o modernizmie, „Znak” 2002/7.

[4] Kracik J., Antymodernistyczna kampania, „Znak” 2002/7, http://www.znak.com.pl/ znak/kracik566.html.

[5] Krasicki J., Eschatologia i mesjanizm. Studium światopoglądu Mariana Zdziechowskiego, Kraków 1994.

[6] Padoł R., Filozofia religii polskiego modernizmu, Wydawnictwo Literackie Kraków 1982.

[7] Skoczyński J., Pesymizm filozoficzny Mariana Zdziechowskiego, Kraków 1983.

[8] Skoczyński J., Sympatyk modernizmu religijnego, „Znak”1983/8.

[9] Skoczyński J., Wartość pesymizmu, Kraków 1994.

\footnotetext{
${ }^{37}$ Por. J. Skoczyński, Pesymizm filozoficzny..., s. 46.

${ }^{38}$ Ibidem, s. 408.

${ }^{39}$ Por. ibidem, s. 402.
} 
[10] Stecko J., Próba współczesnej interpretacji koncepcji diabła jako metafory zła na przykładzie myśli Leszka Kołakowskiego, [w:] Etyka a zło, red. D. Probucka, Kraków 2013.

[11] Stomma S., Oczyma świadka, [w:] J. Skoczyński, Wartość pesymizmu, Kraków 1994.

[12] Wesołowska E.N., Działać przed katastrofa, Warszawa 1994.

[13]Zdziechowski M., Pesymizm, romantyzm a podstawy chrześcijaństwa, t. II, Warszawa 1993.

[14]Zdziechowski M., Szkice literackie, Warszawa 1900.

\section{THE IDEA OF CATHOLIC MODERNISM IN THE MARIAN ZDZIECHOWSKI'S PHILOSOPHICAL QUESTS}

This article is another one in the series, which discusses the ethical issues that arise in the Polish philosophy. Once again we are inspired by the concept of Marian Zdziechowski, but this time it is a question rarely undertaken in the analyzes and studies - the issues of being inspired by catholic modernism in the philosophy of Vilnius thinker. Marian Zdziechowski is a kind of a bridge - between two centuries, between romanticism and positivism, rationalism and idealism, between the ideas of East and West, between logical understanding of the world and the metaphysical conceptualization, between the pascal faith and reason. But Zdziechowski followed his own way, did not fit into any philosophical fashions, consistently clinging to his ideological principles.

Marian Zdziechowski tried to justify the possibility and necessity of faith in God in the face of overwhelming evil of the world. Taking polemic against St. Augustine and yielding to another fascination with such thinkers as Soloviev and Schopenhauer, he tried to find the answers to questions about the causes and possibilities to overcome evil, which seem to be the most important for the thinker. When constructing his philosophical belief in the book "Pessimism, romanticism and the foundations of Christianity", Zdziechowski also turn on the ideas of catholic modernism in his intellectual pursuits. He asked basic questions about modernism as a challenge for contemporary faith and the possibility of dialogue with the new trends.

Searching for answers at various levels, including those that serve in-depth of religious reflection, he took an attitude $f$ an intellectualist involved in Christian thought, however, free from the prejudices and fears of creative exploration. The aim of this paper is an attempt to familiarize the idea of catholic modernism in terms of Marian Zdziechowski, with special focus on the evil and the pessimism associated with it.

Keywords: catholic modernism, Christianity, evil, pessimism, Zdziechowski

DOI:10.7862/rz.2014.hss.49

Przesłano do redakcji: czerwiec 2014

Przyjęto do druku: październik 2014 